УДК 666.97

\title{
USE OF SELF-COMPACTING CONCRETE DURING RECONSTRUCTION OF THE BUILDING FOR THE ADMINISTRATION SERVICE CENTRE
}

\author{
S. Bugayevskyi, Assoc. Prof., Ph. D. (Eng.), Ye. Voronova, Ass. Prof., O. Shtefan, P. G., \\ Kharkov National Automobile and Highway University
}

\begin{abstract}
Twophase introduction of superplasticizer additive influence on the properties of concrete mixture was researched. The obtained results allowed concreting of strengthening for the columns building. Herewith, $40 \%$ of SP additive together with $12 \%$ of mixing water were introduced directly into the concrete mixer truck at the moment of its arrival to the construction site, with subsequent agitation of concrete mixture.
\end{abstract}

Key words: self-compacting concrete mixture, flow of cone, obstacle crossing ability, time of flowing through a V-shaped funnel, concrete mixer trucks (mixers), columns, building.

\section{ПРИМЕНЕНИЕ САМОУПЛОТНЯЮЩЕГОСЯ БЕТОНА ПРИ РЕКОНСТРУКЦИИ ЗДАНИЯ ПОД ЦЕНТР ПРЕДОСТАВЛЕНИЯ АДМИНИСТРАТИВНЫХ УСЛУГ}

\section{С.А. Бугаевский, доц., к.т.н., Е.М. Воронова, доц., О.Н. Штефан, асп., Харьковский национальный автомобильно-дорожный университет}

\begin{abstract}
Аннотация. Реализована технология бетонирования железобетонных конструкиий с применением самоуплотняющегося бетона. Проведено исследование двухстадийного введения добавки суперпластификатора на свойства бетонной смеси. Обеспечена сохранность реологических свойств самоуплотняющейся бетонной смеси при доставке ее автобетоносмесителями на строительную площадку.
\end{abstract}

Ключевые слова: суперпластификатор, самоуплотняющийся бетон, бетонная смесь, распльв конуса, автобетоносмеситель.

\section{ЗАСТОСУВАННЯ САМОУЩІЛЬНЮВАНОГО БЕТОНУ ПІД ЧАС РЕКОНСТРУКЦІЇ БУДІВЛІ ПІД ЦЕНТР НАДАННЯ АДМІНІСТРАТИВНИХ ПОСЛУГ}

\section{С.О. Бугасвський, доц., к.т.н., Е.М. Воронова, доц., О.М. Штефан, асп., Харківський національний автомобільно-дорожній університет}

Анотація. Реалізовано технологію бетонування залізобетонних конструкиій із застосуванням самоущільнюваного бетону. Проведено дослідження двостадійного введення добавки суперпластифікатора на властивості бетонної сумімі. Забезпечено збереження реологічних властивостей самоущільнюваної бетонної суміші під час доставки ї̈ автобетонозмімувачами на будівельний майданчик.

Ключові слова: суперпластифікатор, самоущільнюваний бетон, бетонна суміш, розплив конуса, автобетонозмімувач.

\section{Introduction}

The process of concreting monolithic reinforced-concrete structures at the construction site involves the delivery of concrete mixture from the factory by concrete mixer trucks (mixers); herewith, the quality of erected structures directly depends on preservation, uniformity and 
workability of concrete mixture (rheological properties) during transportation, unloading and placing.

\section{Analysis of publications}

Uniformity of the mixture is conditioned upon the minimum required cohesion which rules out the possibility of mixture segregation and water separation. Workability is the ability of concrete mixture to take a predetermined shape relatively easily and fast, while retaining solidity and uniformity of concrete structure; it is determined by its viscosity at the moment of filling of timbering and the degree of plasticity, i.e. plasticity for being deformed without breaking of continuity.

The change in rheological properties of concrete mixture is significantly affected by transportation time of concrete mixture, as well as elevated temperature of the environment. This is especially important for self-compacting concretes, for which the use of vibration during placing is strictly prohibited and only controlled slight vibrating is allowed (local tapping or simple rodding in the relevant areas) [1].

The need to enhance the working life of concrete mixture determines the suitability of using the method of «late» introduction of additives («two-step mixing method»). The workability retention time can be prolonged by dosing the superplasticizer in portions. The number of portions of superplasticizer introduction is usually taken equal to two; herewith, there are two approaches to dosing: an introduction of another $0,2 \%$ of cement weight over the initial superplasticizer quantity after loss of mobility by concrete mixture, or separate introduction of superplasticizer during mixture preparation and immediately before placing into the structure [2-7].

\section{Purpose and problem statement}

The main objective of the reconstruction is to adapt the existing building on 144, Traktorostroiteley Avenue (Kharkiv) for the Administrative Service Center (TsPAU) with the appropriate set-up of main and auxiliary technical premises: the entrance lobby, the citizens reception hall (front-office), work-rooms (back office), archives rooms, premises for sanitaryand-amenity and medical services of the employees (undressing rooms, water closets, dining room, etc.).
The reconstruction of the building involves the following architectural and construction measures:

- dismantling of the existing partitions (except for the walls of staircases and elevator shafts) and erection of the new ones according to the developed technological planning solutions to ensure TsPAU operation, as well as sanitary and fire regulations;

- dismantling of curtain wall panels with erection of walls of gas-concrete blocks with arrangement of band glazing and cladding of facades with modern materials using parametric decorative glazing and ventilated facades with a protective screen made of ceramic granite tiles; - dismantling of the existing floorings above the crawl space, in order to bring the floors of the semi-basement to a common level with arrangement of the floor construction on the ground;

- thermal modernization of the coating;

- arrangement of the roof boiler-room.

The building under reconstruction is the former «Consumer Services Centre» («Dom Byta») according to TP 282-1-10 and is a 5-storey detached building with basement and technical storeys, with total dimensions within the axes of $42 \times 30 \mathrm{~m}$ and an additional building from the side of the main entrance from the NorthWestern side (Fig. 1, a).

Thermal modernization of the coating involves replacement of heat-insulating and waterproofing layers using effective heat-insulation materials with an increase in thermotechnical characteristics not lower than those required for thermal protection of buildings. The project also involves heat insulation of the basement walls to a depth of soil freezing. The floor level of the existing semi-basement within axes $1-3$ is taken as the construction zero mark, which corresponds to an absolute mark of 171,65.

For articulation of the main entrance and arrangement of the entrance lobby, an additional glass building is arranged from the side of the Main facade. Revolving (rotating) doors with a built-in air curtain are provided as the filling of the door openings of the main entrance. On both sides, additional doors are provided for evacuation and entering of citizens with disabilities into the building. From the SouthEast side of the building (yard facade), two emergency exits are also provided. 


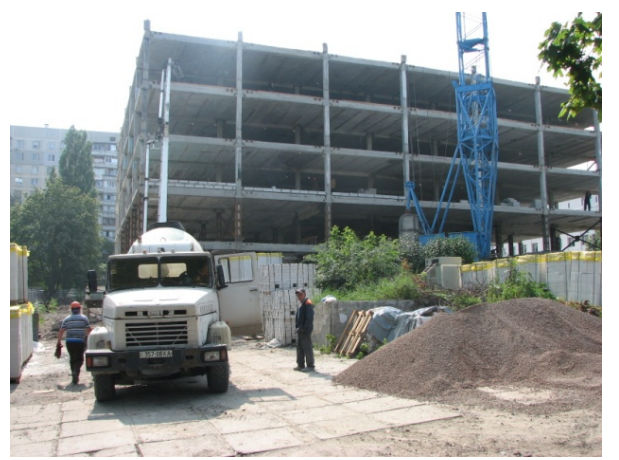

b

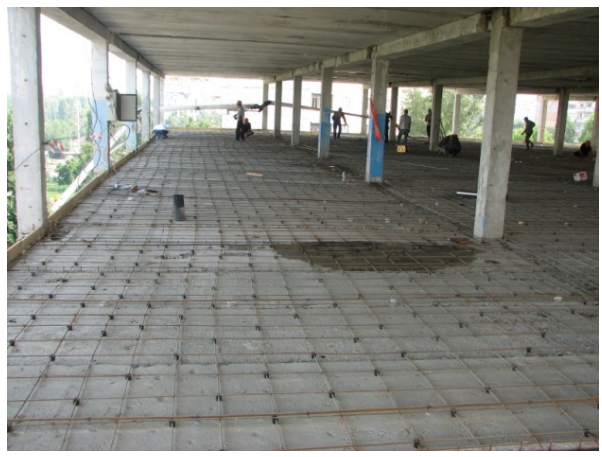

c

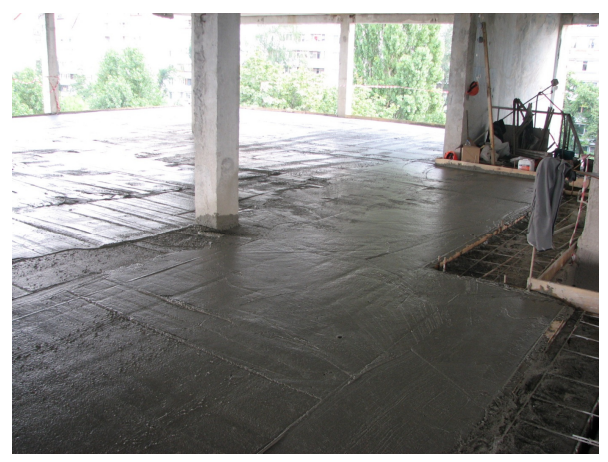

d

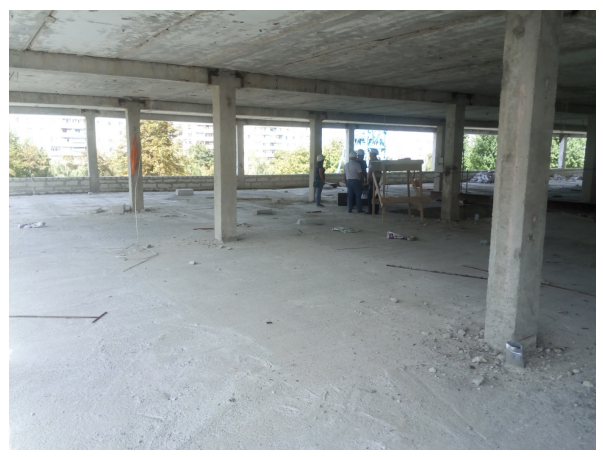

Fig. 1. Strengthening of floorings using self-compacting concrete: $a$ - view of the building; $b$ - layout of armoring; $\mathrm{c}$ - freshly placed concrete mixture; $\mathrm{d}$ - finished flooring

The project involves extension of the existing double-height space of the vestibule group with arrangement of the Citizens reception hall. Reception of citizens is provided in one level. The existing open stairs are dismantled.

For connection between the floors and evacuation, the existing vertical connections are preserved, since the longitudinal walls of the staircases are the stiffening diaphragms. The building has two main staircases and two elevator shafts. To access the technical storey level and the roof, technical stairs are provided, made in a separate room. Two elevators are provided in the central part of the building: passenger one and freight-passenger one for use by the TsPAU employees.

The semi-basement includes: hall, reception, citizens reception hall with a waiting area and a children's zone, branch of a bank (built-in premises of cash desks), municipal-guard post, and sanitary rooms for visitors.

The first storey comprises amenity rooms for the front office employees (operators of the Citizens reception hall), office of the TsPAU head, server room, back office of the Pension Fund and TsPAU employees. The above-lying storeys comprise executive offices and work-rooms of the employees of TsPAU, the Civil Registry Office, the Administration for state registration of legal entities and individuals, the Chief administration of the migration service, the Pension Fund, the Administration of labour and social protection, as well as the Department of maintenance of territorial register of citizens. Separate archives rooms are provided for each of the services. Water closets with service areas for cleaning utensils storage, and switchboard rooms are provided on the storeys. The premises of the technical storey comprise: roof boilerroom with two heat points. Fencing is provided around the roof perimeter.

Design of the exterior walls: masonry of gasconcrete blocks with facade heat insulation of mineral-wool boards with a ventilated gap and cladding with industrial elements (V.4 class according to DSTU B V.2.6-34), consisting of:

- interior finish (plasterwork, paintwork);

- gas-concrete blocks $\left(U=500 \mathrm{~kg} / \mathrm{m}^{3}, l=0,16\right)$ $300 \mathrm{~mm}$;

- heat insulator - ROCKWOOL WENTIROCK mineral-wool boards $(l=0,036)-50 \mathrm{~mm}$,

- wind barrier;

- air space;

- metal substructure for ventilated facades;

- cladding - ceramic granite;

The exterior walls of the semi-basement along the $\mathrm{E}$ axis below the ground level mark are heatinsulated with mineral-wool boards to the frost depth. The existing basement walls of precast reinforced-concrete foundation blocks are left unchanged. 
Coating structure: combined (PK-4 type according to Appendix 2 of DBN V.2.6-14-97, volume 1) with heat insulation of mineral-wool boards and roll roofing materials with internal water drain (1,5-2,5\% slope), consisting of:

1) waterproofing covering:

- top layer - Bikroelast EPP-K (1 layer);

- bottom layer - Bikroelast EKP-P (2 layers);

- reinforcing fibreglass mesh on

TEKHNONIKOL No. 21 mastic (1 layer);

2) heat-insulating layer:

- top layer-mineral-wool boards for surface stiffness TECHNOROOF V70 - $40 \mathrm{~mm}$;

- bottom layer - mineral-wool boards for surface stiffness TECHNOROOF H30 - $100 \mathrm{~mm}$;

- vapor-proof barrier - Bikroelast TPP;

- levelling screed of sand-cement mortar $15 \mathrm{~mm}$;

- sloping layer - Polysterene concrete IZOCAP -50-310 mm;

3) monolithic reinforced-concrete slab for strengthening made of self-compacting concrete $-50 \mathrm{~mm}$;

4) existing precast reinforced-concrete slabs of flooring $-220 \mathrm{~mm}$.

Based on the requirements for roof boiler-room location, the roof sections with arrangement of cement-sand screed under waterproofing covering and hard asphalt-concrete surfacing are provided.

The translucent structures (filling of window openings): aluminum profile with filling of triple-pane window with air medium of the chambers: 4i-16-4M1-16-4i. The design of the multiple glass unit of the entrance lobby: triplepane window filled with dry air 6 ESG MF-20 Silicon-6-20 Silicon-4/4/1, where:

6 ESG MF is a $6 \mathrm{~mm}$ external tempered glass with power-saving and sun-protection features;

20 Silicon is an aluminum section of $20 \mathrm{~mm}$ width with double UV-proof sealing;

$4 / 4 / 1$ is internal triplex glass consisting of two glasses with $4 \mathrm{~mm}$ thickness each.

The foundations are the existing precast reinforced-concrete ones. The frame consists of the existing reinforced-concrete columns and cross-beams under II-04 series. Reinforcedconcrete columns were strengthened in two ways: the edge columns along the perimeter of the building were strengthened with metal casing and covered with plaster; and the middle columns, after strengthening with metal casing, were further concreted with the use of selfcompacting concrete placed into timbering.
Technological sequence of works on plastering of the edge columns.

1) Column surface preparation.

Clean metal casings ( $L 100 \times 8)$ mounted on the columns, and apply Ceresit CD30 with $1 \mathrm{~mm}$ thickness on them with a putty knife (amount of mixing water is according to instructions). The concrete of the columns should be primed with the solution of Ceresit CC81 emulsion with PTs II/A Sh-400R cement in the ratio of $2: 1$ by volume.

2) Execution of plastering works.

The first layer of plaster should be made of Ceresit CT29 polymer-cement putty with addition of Ceresit CC 81 (composition: $10 \mathrm{~kg}$ of $\mathrm{CT} 29+0,8$ liter of CC81 2 liters of water) up to the level of the protruding metal plates which weld the casing strengthening angles. Install the identical corner angles for plastering works at a distance of $20 \mathrm{~mm}$ from the metal strengthening angles and make the second layer of Ceresit CT29 plaster. Technological sequence of works on further concreting of the middle columns.

Install the timbering around the column to the middle of its height; whereafter carry out concreting with the use of self-compacting concrete. After two-day curing of concrete in the timbering, remove the timbering from the concrete and reset the timbering for further concreting of the upper part of the column. After two-day curing of concrete of the upper part, remove the timbering from the concrete.

Floorings are the existing precast reinforcedconcrete slabs of flooring, strengthened with monolithic reinforced-concrete slab of selfcompacting concrete with $50 \mathrm{~mm}$ thickness. Technological sequence of performance of works on strengthening of precast reinforcedconcrete floorings.

Clean and wash the flooring concrete surface with pressure water jet using Karcher installation according to SNiP 3.04.01-87 and DBN V.2.6-22-2001. Lay a grid of «Ekibar» AKBP-5-600 composite armoring with a pitch of $150 \times 150 \mathrm{~mm}$, with the provision of the protective layer from the top of the flooring slab of $15 \mathrm{~mm}$ using plastic clips. Apply Ceresit CD30 adhesion coating in two layers with a total thickness of $2 \mathrm{~mm}$ (consumption of $5 \mathrm{~kg} / \mathrm{m}^{2}$ ) on a slightly damp surface of the concrete, in order to ensure the adhesive strength of the fresh layer of concrete with the base of not less than 1,7 MPa. Place self-compacting concrete with 
$50 \mathrm{~mm}$ thickness, not later than $60 \mathrm{~min}$ from the moment of the adhesive coat application.

Concrete composition:

- PTs II/A-Sh-400R cement - $500 \mathrm{~kg}$;

- crushed stone with 5-10 mm fraction $-1,150 \mathrm{~kg}$;

- granite screenings - $200 \mathrm{~kg}$;

- sand - $600 \mathrm{~kg}$;

- FK 59 superplasticizer additive, $1 \%$ of cement weight $-5 \mathrm{~kg}$;

- AV-1 multi-purpose fiber - 0,5 kg;

- mixing water -250 liters.

The designed partitions are made of gypsum plasterboards by KNAUF frame, of ceramic bricks in wet and technical premises, glazed ones are of aluminum profile with reinforced glass filling. Flights of stairways are the existing reinforced-concrete ones.

Doors: external ones are glazed, made of aluminum profile with filling of multiple glass unit; internal ones are glazed, made of aluminum profile with filling of reinforced glass, fire-resisting metal ones. Floors are made of ceramic tiles and linoleum. Interior finish of walls and partitions is made of ceramic tiles; painting is with aqueous emulsion inks. Ceilings are of Armstrong type, gypsum plasterboard / moisture-resistant gypsum board by KNAUF frame. Strengthening of the existing precast reinforced-concrete slabs of the flooring was

a

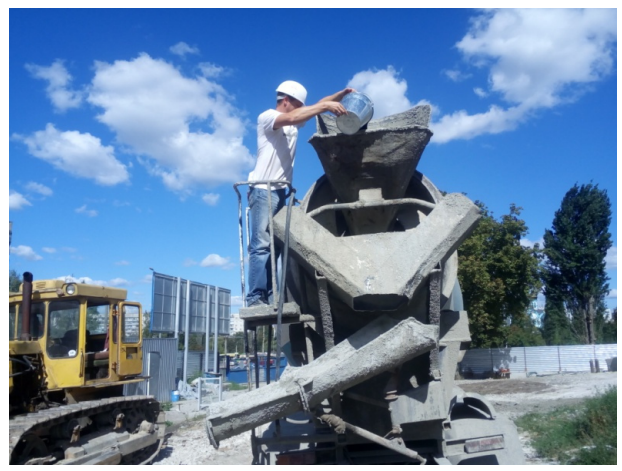

b

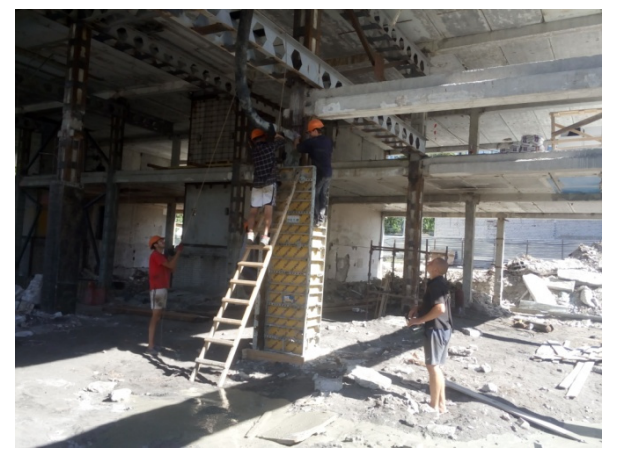

carried out using self-compacting concrete delivered by concrete mixer trucks from the site of reinforced-concrete products of «Zhilstroy-2» Additional Liability Company. Transportation of concrete mixture was carried out during 60-90 minutes at the air temperature of approximately $27-29{ }^{\circ} \mathrm{C}$. As a result, the concrete mixture having, during preparation, the flow of cone of approximately $67-70 \mathrm{~cm}$ was losing the necessary mobility.

The aim of the conducted laboratory and pilot works is to ensure retaining of the rheological properties of self-compacting concrete over time. We set a task to study the effect of twostage introduction of superplasticizer additive on the rheological properties of self-compacting concrete. The studies were conducted in the laboratory of the site of reinforced-concrete products of «Zhilstroy-2» Additional Liability Company in Kharkov.

In the course of the laboratory tests, the possibility of separate introduction of the superplasticizer (SP) additive was checked, in order to ensure preservation of self-compacting concrete mixture when it is delivered by concrete mixer trucks from the concrete mixing station to the point of placing to strengthen the columns of the building under reconstruction (Fig. 2).

c
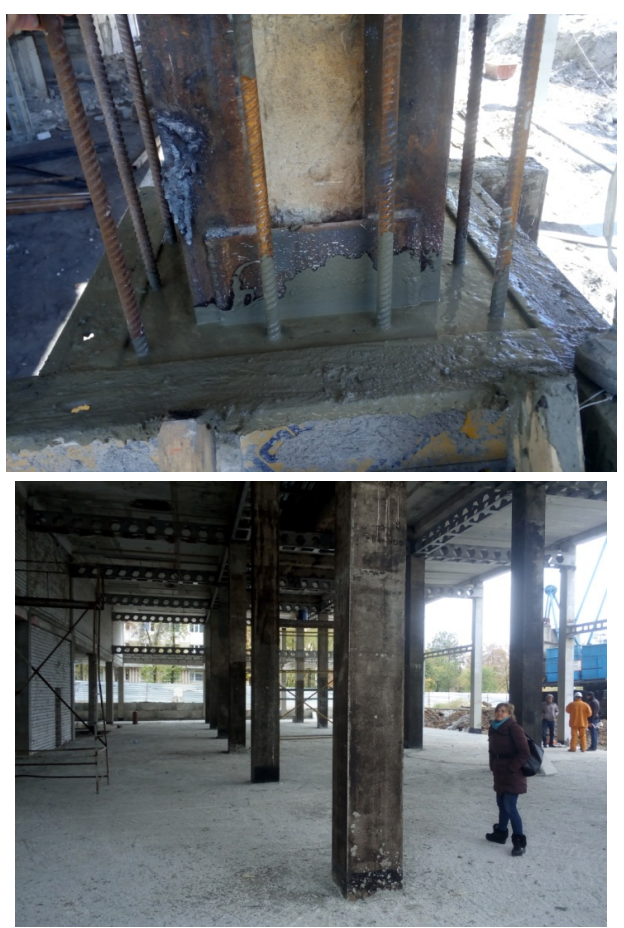

Fig. 2. Concreting of columns of self-compacting concrete: a - the second stage of superplasticizer introduction; $b$ - concreting of strengthening of the lower part of the column; $c$ - placed selfcompacting concrete; $d$ - the finished columns after strengthening 
During the concrete mixture preparation, 60 and $70 \%$ of the required amount of SP additive were introduced with $88 \%$ of mixing water, in order to provide cone slump of $20 \mathrm{~cm}$ to ensure mixing during transportation. The rest of mixing water $(12 \%)$ and SP additive (40 and $30 \%$, respectively) were introduced after 1,5 hours, in order to compare preservation with the parameters of the composition prepared directly at the concrete mixing station (the test composition). The test composition was placed into the mould after 1,5 hours of curing, simulating the delivery to the construction site.

The laboratory tests showed that, for all three compositions, the flow of cone was $680 \mathrm{~mm}$, obstacle crossing ability was 0,92 , and the time of flowing through a V-shaped funnel is $4-5 \mathrm{sec}$. The maximum compressive strength at the age of 3 and 28 days was shown by the composition with introduction of 60 and $40 \%$ of SP, respectively; and the minimum compressive strength was shown by the test composition.

Herewith, the amount of mixing water in case of two-stage SP introduction did not exceed the test composition, and was even less by $3-5 \%$.

\section{Conclusions}

The obtained results allowed concreting of strengthening for the columns of the 1st storey of the 5-storey building (Fig. 2). Herewith, $40 \%$ of SP additive together with $12 \%$ of mixing water were introduced directly into the concrete mixer truck at the moment of its arrival to the construction site, with subsequent agitation of concrete mixture during 3-4 min (Fig. 2, a). Concreting of strengthening for the columns of the 1st storey having height of about $10 \mathrm{~m}$ was carried out with the use of timbering in two stages (Fig. 2, b, c).

\section{References}

1. Добавки на основе эфиров поликарбоксилатов для изготовления вибрационных и самоуплотняющихся бетонов: СТО 70386662-306-2013. - М.: ООО «БАСФ Строительные системы», 2013. - 69 с.

2. Kordts Stefan Steuerung der Verarbeitbarkeitseigenschaften von Selbstverdichtendem Beton als Transportbeton / Kordts Stefan, Grube Horst // Betontechnische Berichte, 2001-2003 Verein dtsch. Zemet- werke, Forschungsinst. Zementing. - Dusseldorf: Bau+Techn, 2004. - p. 103-112.

3. Stefan Kordts Wolfgang Breit Assessment of Fresh Concrete Properties of Self Compacting Concrete / Kordts Stefan // FTB (Ready-mixed Concrete Research Association). - 2004. - P. 113-124.

4. Салих Ф. Повышение сохранности бетонной смеси при поэтапном введении добавок / Ф. Салих, С.В. Коваль // Вісник ДНАБА: зб. наук. пр. Серія: Сучасні будівельні матеріали. - 2013. Вип. 1(99). - С. 145-150.

5. Салих Ф. Моделирование свойств самоуплотняющегося бетона при поэтапном введении добавок / Ф. Салих, С. Коваль // Вісник Національного технічного університету «ХПІ». Хімія, хімічна технологія та екологія. - 2013. - № 57. C. $38-44$.

6. Салих Ф. Влияние повторного введения добавок на реологию и твердение цементного раствора как матрицы бетона / Ф. Салих, С.В. Коваль // Строительство и техногенная безопасность: сб. науч. тр. - 2013. - Вып. 47. - С. 39-43.

7. Бычков М.В. Самоуплотняющиеся бетоны пониженной плотности с применением вулканического туфа // Инженерный вестник Дона: электронный научный журнал. -2013. - №3. - 15 с. - Режим доступа: http://cyberleninka.ru /article/n /samouplotnyayuschiesya-betonyponizhennoy-plotnosti-s-primeneniemvulkanicheskogo-tufa.

\section{References}

1. STO 70386662-306-2013. Dobavki na osnove jefirov polikarboksilatov dlja izgotovlenija vibracionnyh $i$ samouplotnjajuschihsja betonov. [Additives based on polycarboxylate ethers for producing vibration and self-compacting concrete. Moskow, BASF Building Systems Publ., 2013. $69 \mathrm{p}$.

2. Kordts Stefan, Grube Horst Steuerung der Verarbeitbarkeitseigenschaften von Selbstverdichtendem Beton als Transportbeton. Betontechnische Berichte, 2001-2003 Verein dtsch. Zemetwerke, Forschungsinst. Zementing. Dusseldorf: Bau+Techn, 2004. pp. 103-112.

3. Stefan Kordts, Wolfgang Breit Assessment of Fresh Concrete Properties of Self Compacting Concrete, FTB (Ready-mixed 
Concrete Research Association), 2004, pp. 113-124.

4. Salih F., Koval' S.V. Povyshenie sohrannosti betonnoj smesi pri pojetapnom vvedenii dobavok [Improving the safety of concrete mix in a phased intro-Denia additives]. Visnik DNABA. Suchasni budivel'ni materialy. Zbirnik naukovih prac' [Bulletin DNABA. Modern Construction Materials. Scientific works]. 2013. Vol. 2013-1 (99). pp. 145-150.

5. Salih F., Koval' S. Modelirovanie svojstv samouplotnjajuschegosja betona pri pojetapnom vvedenii dobavok [Modeling properties of SCC in a phased introduction of additives]. Visnik Nacional'nogo tehnichnogo universitetu «HPI». Himija, himichna tehnologija ta ekologija [Proceedings of the National Technical University «HPI». Chemistry, Chemical Engineering and Ecology]. 2013. no. 57. pp. 38-44.

6. Salih F., Koval' S.V. Vijanie povtornogo vvedenija dobavok na reologiju i tverdenie cementnogo rastvora kak matricy betona.
Sbornik nauchnyh trudov [Effect of repeated administration of additives on the rheology and hardening of the cement slurry as the concrete matrix]. Stroitel'stvo i tehnogennaja bezopasnost'. [Collection of scientific works. Construction and technological safety], 2013. Vol. 47. pp. 39-43.

7. Bychkov M.V. Samouplotnjajushhiesja betony ponizhennoj plotnosti $s$ primeneniem vulkanicheskogo tufa [MV SCC low density with volcanic tuff]. Jelektronnyj nauchnyj zhurnal Inzhenernyj vestnik Dona [Electronic scientific journal Engineering Don Bulletin], 2013. no. 3. 15 p. Available at: http: // cyberleninka.ru /article/n/ samouplotnyayuschiesya-betonyponizhennoy-plotnosti-s-primeneniemvulkanicheskogo-tufa.

Рецензент: В.П. Кожушко, профессор, д.т.н., ХНАДУ. 